\title{
Factors Influencing Sustainable Purchasing Behaviour of Remanufactured Robotic Lawn Mowers
}

\author{
Daan Kabel ${ }^{1, *(\mathbb{D})}$, Mattias Elg ${ }^{1}$ and Erik Sundin ${ }^{2}$ \\ 1 Division of Logistics and Quality Management, Department of Management and Engineering, \\ Linköping University, SE-58183 Linköping, Sweden; mattias.elg@liu.se \\ 2 Division of Environmental Technology and Management, Department of Management and Engineering, \\ Linköping University, SE-58183 Linköping, Sweden; erik.sundin@liu.se \\ * Correspondence: daan.kabel@liu.se
}

check for

updates

Citation: Kabel, D.; Elg, M.; Sundin, E. Factors Influencing Sustainable Purchasing Behaviour of

Remanufactured Robotic Lawn

Mowers. Sustainability 2021, 13, 1954 https://doi.org/10.3390/su13041954

Academic Editor: Riccardo Testa

Received: 19 January 2021

Accepted: 8 February 2021

Published: 11 February 2021

Publisher's Note: MDPI stays neutral with regard to jurisdictional claims in published maps and institutional affiliations.

Copyright: (c) 2021 by the authors. Licensee MDPI, Basel, Switzerland. This article is an open access article distributed under the terms and conditions of the Creative Commons Attribution (CC BY) license (https:// creativecommons.org/licenses/by/ $4.0 /)$.

\begin{abstract}
The lack of consumer acceptance for remanufactured products is preventing the transition towards sustainable consumption. When knowledge about remanufacturing among consumers is limited, more insight is required into the consumer's expectations. The purpose of this paper is to examine the consumer's expectations and willingness to engage in sustainable purchasing behaviour when considering buying remanufactured robotic lawn mowers. The theory of planned behaviour and variables from green marketing help form the research model, which was tested empirically using survey data from 118 samples. The results indicate that sustainable purchasing behaviour of remanufactured robotic lawn mowers is primarily influenced by the consumer's attitude and evaluation of the remanufactured product, and less so by external influences. Consumers expecting high product quality, low price, and low risk, had a positive evaluation and were therefore more willing to engage in sustainable purchasing behaviour of remanufactured robotic lawn mowers. More concisely, consumers value performance and price reductions, and worry about the time the remanufactured robotic lawn mower remains functional. Environmental knowledge among consumers is sufficient but cannot be fully translated into positive evaluations and sustainable purchases of remanufactured robotic lawn mowers. This research provides guidance for how remanufacturing firms can improve their circular marketing and remanufacturing strategies.
\end{abstract}

Keywords: theory of planned behaviour; structural equation modelling; sustainable consumption; circular economy; remanufacturing

\section{Introduction}

In the process of transcending towards sustainable consumption, numerous circular models, practices and principles have been put forward [1]. The approaches are originating from the concept of circular economy which is the systematic shift towards reducing, reusing, and recycling materials [2]. These circular approaches, which are based on limited resources and continuous growth, have gained major attention worldwide as they foster social well-being and environmental protection [3,4]. One of these approaches is remanufacturing, which is an industrial process to obtain value from worn-out products by reusing materials. For remanufacturing to work, consumers and remanufacturing firms need to be closely coupled [5]. Consumers are central within the remanufacturing process, because consumers are responsible for returning cores, repairing, reusing, and purchasing remanufactured products, allowing the circularity of materials within the system to emerge. This is necessary when making systems self-sustaining. However, the consumer's perception and knowledge of remanufactured products is still limited [6], thus placing them further away from each other, and holding back sustainable consumption. Govindan et al. [7] revealed that customers from India are less aware of remanufactured automotive parts and believe them to have a short product lifespan and to be of low-quality. Another problem is the increasing world population, with high levels of consumption resulting in resource 
shortages. When consumers are searching for greater wealth, the demand for valuable products and materials increases [4]. These problems are in line with Govindan et al. [7], who claim that the largest barrier when transcending to a circular economy is the consumer's willingness to adapt to remanufactured products. They also believe that there is no specific market for selling remanufactured products. In a study on more than 200 remanufacturing companies in Europe it was found that more than $70 \%$ of them had customers that did not recognized the concept of remanufacturing and its benefits [8]. This means that this customer recognition challenge is spread out in many remanufacturing industrial sectors. In addition, Vogt Duberg et al. [9] describe "remanufacturing market knowledge" as a prerequisite factor for original equipment manufacturers (OEMs) to consider when setting up a remanufacturing operation, in which it is important to investigate the willingness to purchase remanufactured products. The willingness to purchase remanufactured products belongs to a larger domain, that is sustainable consumption. Sustainable consumption is about promoting sustainable lifestyles, increasing resource efficiency and preventing environmental degradation [10].

In this journey towards sustainable consumption, in order to bring consumers on board, more insight is required into the consumer's willingness to engage in sustainable purchasing behaviour. To address these concerns, the purpose of this paper is to examine the consumer's expectations and willingness to engage in sustainable purchasing behaviour when considering buying remanufactured products. By doing so, we support the large body of research examining the effects towards sustainable consumption. The theory of planned behaviour (TPB) proposed by Ajzen [11] is used as a lens through which to understand purchase intentions for remanufactured products. In this paper, we collaborate with Husqvarna to provide valuable insight into the consumer's willingness to engage in sustainable purchasing behaviour of remanufactured robotic lawn mowers. Through this process, we support remanufacturing firms in establishing appropriate marketing and remanufacturing strategies. The marketing strategies for conservation behaviours must contain information about the benefits, and contain messages framed in such a way it appeals to the individual [12,13]. The remainder of this paper is structured as follows. In Section 2, the research model is proposed using previous research and the theory of planned behaviour. The research model is tested empirically via a survey. Section 3 explains the methodology and Section 4 shows the results of the structural equation model. Section 5 provides implications for remanufacturing firms, and finally Section 6 contains the conclusions of this study and suggestions for future research.

\section{Previous Research and Model Development}

\subsection{Examining Drivers of Sustainable Consumption: A Theoretical Perspective}

Previous research aiming to explain and predict sustainable purchasing behaviour among consumers guided the development of our research model. To foresee sustainable behaviour among consumers, various predictive theories-as shown in Table 1-have been proposed, modified and applied to predict this behaviour. To provide an overview of previously applied theories, theories were divided up based on their underlying assumption, that is a description of how consumers behave and respond to green products and sustainable behaviour. In this paper, these assumptions focus on the consumer's emotions, values, goals, knowledge and structure, in other words the influence of the external environment.

Table 1. An overview of the most common predictive theories used to explain sustainable behaviour.

\begin{tabular}{cccc}
\hline Focus & Assumption & Predictive theories & Applied in \\
\hline & $\begin{array}{c}\text { Individuals engage in } \\
\text { behaviour because of } \\
\text { reactions and } \\
\text { Eppraisal from the } \\
\text { surrounding world. }\end{array}$ & $\begin{array}{c}\text { Triangular theory of love } \\
\text { [14], Emotion regulation } \\
\text { theory [15] and Appraisal } \\
\text { theory of emotion [16] }\end{array}$ & $\begin{array}{c}\text { Kong et al. [17], } \\
\text { Kand Waglajlic et al. [18] } \\
\text { and Wang and Wu [19] }\end{array}$ \\
& & & \\
\hline
\end{tabular}


Table 1. Cont.

\begin{tabular}{|c|c|c|c|}
\hline Focus & Assumption & Predictive theories & Applied in \\
\hline Values & $\begin{array}{l}\text { Individuals engage in } \\
\text { behaviour because of } \\
\text { a set of guiding } \\
\text { principles. }\end{array}$ & $\begin{array}{l}\text { Value-norm-belief theory } \\
\text { [20], Theory of basic } \\
\text { human values [21] and } \\
\text { Theory of consumption } \\
\text { values [22] }\end{array}$ & $\begin{array}{c}\text { Kang and Moreno [23], } \\
\text { Jacobs et al. [24], } \\
\text { Thogersen et al. [25], } \\
\text { Biswas and Roy [26] and } \\
\text { Liobikiene et al. [27] }\end{array}$ \\
\hline Goals & $\begin{array}{l}\text { Individuals make } \\
\text { decisions based on } \\
\text { risk and aim to } \\
\text { maximize utility and } \\
\text { benefit to achieve } \\
\text { their goal. }\end{array}$ & $\begin{array}{c}\text { Goal framing theory [28], } \\
\text { Diffusion of innovation } \\
\text { [29], Innovation } \\
\text { resistance theory [30], } \\
\text { Prospect theory [31], } \\
\text { Perceived value literature } \\
\text { [32], Regulatory focus } \\
\text { theory [33] and Expected } \\
\text { utility theory [34] }\end{array}$ & $\begin{array}{c}\text { Liobikiene et al. [35], } \\
\text { Wang et al. [36], Wang } \\
\text { and Hazen [37], Hazen } \\
\text { et al. [38], Wang et al. } \\
\text { [39], Cleveland et al. [40] } \\
\text { and Kushwah et al. [41] }\end{array}$ \\
\hline Knowledge & $\begin{array}{c}\text { Individuals engage in } \\
\text { behaviour because of } \\
\text { their cognitions. } \\
\text { Learning exists when } \\
\text { individuals observe, } \\
\text { evaluate and react to } \\
\text { the world. }\end{array}$ & $\begin{array}{l}\text { Social cognitive theory } \\
\text { [42], Regulatory focus } \\
\text { theory [33] and Social } \\
\text { learning theory [43] }\end{array}$ & $\begin{array}{l}\text { Sun et al. [44], } \\
\text { Yazdanpanah et al. [45] } \\
\text { and Wang et al. [39] }\end{array}$ \\
\hline Structure & $\begin{array}{l}\text { To a large extent, } \\
\text { individuals engage } \\
\text { because of influence } \\
\text { from the social } \\
\text { structure. }\end{array}$ & $\begin{array}{c}\text { Institutional theory [46], } \\
\text { Theory of planned } \\
\text { behaviour [11], System } \\
\text { justification theory [47], } \\
\text { and Theory of reasoned } \\
\text { behaviour }[48,49]\end{array}$ & $\begin{array}{c}\text { Paul et al. [50], } \\
\text { Jimenez-Parra et al. [51], } \\
\text { Jain et al. [52], Vainio and } \\
\text { Paloniemi, [53] and } \\
\text { Judge et al. [54] }\end{array}$ \\
\hline
\end{tabular}

Researchers applying an emotion-driven theory assume that consumers have a connectedness to nature [17] and that they will react with emotional responses towards the preservation of the environment [19]. Social and environmental issues will help shape the consumer's identity and his or her willingness to assist and act on these issues [18]. Researchers who apply a value-driven theory propose that consumers have principles that will guide their sustainable behaviour [23]. These values relate firstly to self-transcendence, which means consumers will care about things that are greater than themselves, and secondly to self-enhancement; that is, when consumers act and care about themselves, and about things that make them feel good [24]. Values can also be more general, as proposed by Sheth et al. [22], which means they are conditional, social, emotional and epistemic in nature. Researchers applying a goal-oriented theory assume that consumers are evaluating marketing variables and seeking information about green products and their environmental consequences to maximize their benefits and satisfy their own personal interests $[27,38,39]$. As informed by perceived value literature and diffusion of innovation, consumers will only engage if they perceive that the green product is better than the alternative. Researchers using a knowledge-oriented theory propose that learning and observing other individuals or groups will strengthen the consumer's willingness to engage in sustainable behaviour. Learning fosters knowledge, which improves the consumer's perceived self-efficacy and confidence to engage successfully [45]. Also, knowledge about green products and their influence on the environment will improve the consumer's capability to predict the outcomes and consequences of a green product [39]. Researchers applying a structure-oriented theory emphasize the external environment or the structure of society. Regulative, normative and cultural institutions provide stability in society, which can predict sustainable behaviour [52]. Consumers behave sustainably or unsustainably because they want to create a positive image for the institutions and groups they belong to [53]. These theories 
assume that individuals make decisions based on norms from their surroundings and the physical objects that can facilitate or prevent sustainable behaviour [50]. To summarize, all proposed theories have their own unique theoretical core and assumptions, allowing certain variables to shine and others to be ignored. In the next section, we argue for and explain the theory of planned behaviour.

\subsection{The Theory of Planned Behaviour (TPB)}

This study was grounded on TPB, which aims to explain and predict human behaviour [11]. TPB was used because it is well-known across different disciplines [55], it can be extended, and it has been successfully applied in previous research relating to sustainable consumption [56]. By extending this theory with other marketing variables, we get valuable insight into how consumers evaluate certain attributes to achieve their goal. TPB is centred around changes in behaviour and decision-making. This allows emerging technologies to reach the prerequisites for effective implementation in society [57]. One central variable within the theory is the intention to perform a specific behaviour [11]. The intention to engage captures the motivational state of an individual, meaning how much effort the individual is willing to invest in order to perform the actual behaviour. Individuals with a strong intention to engage also have a strong intention to perform the actual behaviour [57]. The theory postulates that the intention to engage in a specific behaviour depends on three belief-based variables, namely attitude, perceived behavioural control and subjective norm.

The first variable that influences the intention is the attitude towards the actual behaviour. An individual's attitude is a function of accessible beliefs regarding the actual behaviour's consequences. It is a subjective evaluation of whether the actual behaviour will lead to a certain outcome or provide a certain experience. This evaluation produces a negative or positive attitude towards the actual behaviour. Thus, it is a judgement about whether the individual believes the actual behaviour is likeable or dislikeable, good or bad, pleasant or unpleasant and harmful or beneficial $[58,59]$. The second variable influencing intention is normative beliefs (subjective norm). These beliefs are expectations that other important individuals or groups (e.g. family, friends, co-workers and supervisors) will agree or disagree about performing the actual behaviour. Subjective norm represents how other individuals perceive the intended behaviour and how they put pressure on the individual [11]. It also involves the individual's belief about whether important individuals and groups also are performing this behaviour. If the individual believes important others also are performing the behaviour, this makes it more likely that the individual will also perform the behaviour. The third and final variable is accessible control beliefs, which refers to the ability to perform the behaviour. These control beliefs concern the individual's perceptions of having control about the actual behaviour and the likelihood of successfully performing the behaviour with the desired outcomes. A high degree of perceived behavioural control indicates that the individual is confident about performing the actual behaviour and overcoming expected barriers. Unanticipated events, such as availability or a lack of skills, time, or money, can prevent the individual from having control over a desired behaviour. In the same vein, self-efficacy (from social cognitive theory) relates to perceived behavioural control as a judgement of how well an individual can execute courses of action [43]. TPB brings these concepts of perceived behavioural control or perceived self-efficacy together in a general framework including other higherorder variables [11].

\subsection{Development of Hypothesis}

The hypotheses developed in this paper is based on an extended version of TPB. The marketing variables evaluated by consumers are derived from previous research. The model, shown in Figure 1, represent variables, with relationships predicting purchase intentions for remanufactured products. 'Remanufactured products' refers to remanufactured robotic lawn mowers, which are green products because they has less negative impact on 
the environment during the remanufacturing process compared to manufacturing new robotic lawn mowers.

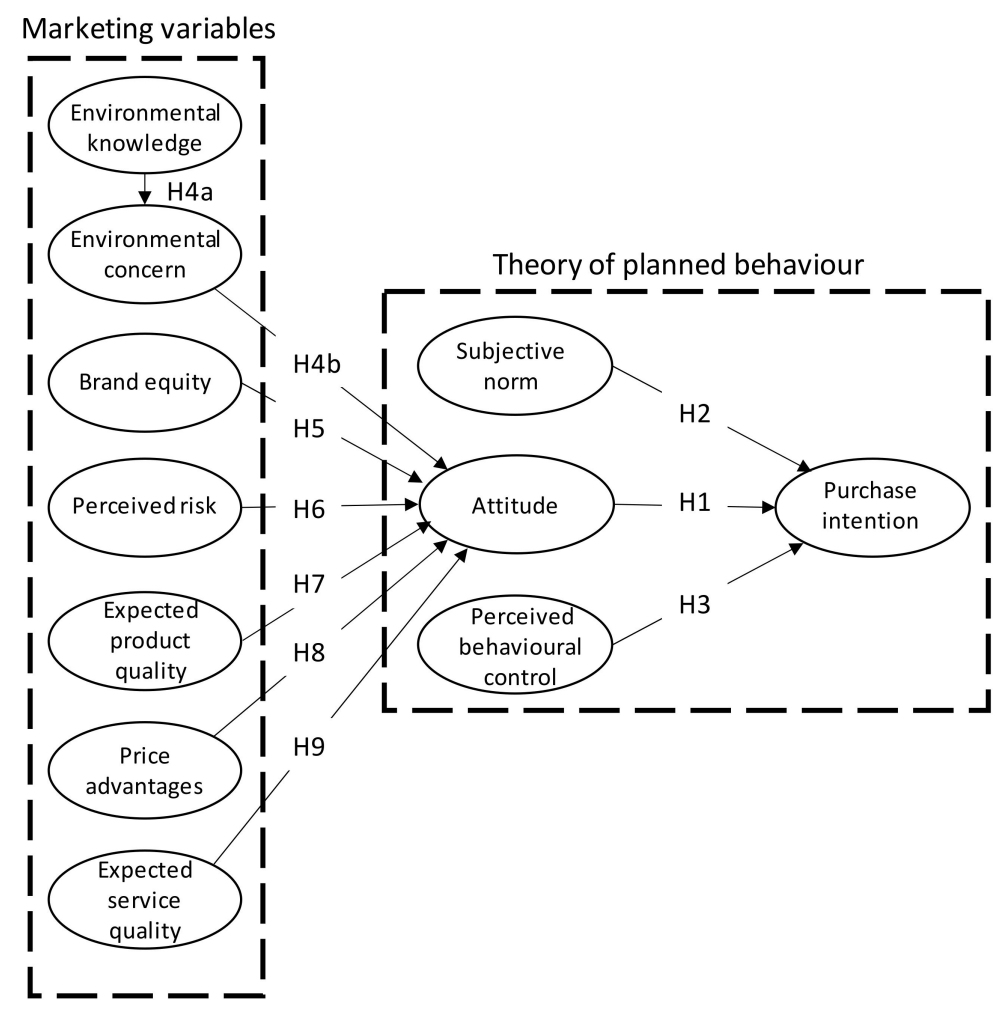

Figure 1. Research model based on theory of planned behaviour (TPB) and marketing variables (Modified from Kabel et al. [60]).

As informed by TPB, the purchase intention is determined by the consumer's attitude, and by subjective and perceived behavioural control. Previous research $[50,51,61]$ on various green products that applied TPB have demonstrated that consumers have a positive attitude (A) and evaluation regarding green products. Likewise, subjective norm (SN) also had positive influences on the purchase intention. The variable 'perceived behaviour control' (C) had negative and positive influences. One possible explanation, as suggested by Barbarossa et al. [62] is that influences change across markets. For a Swedish market, one obstacle—as acknowledged by Kumar [63] and Govindan et al. [7]— can be the lack of an appropriate markets for remanufactured products, which is related to the availability of remanufactured products. Thus, consumers who know where to purchase remanufactured products might also have the confidence to engage in sustainable purchasing behaviour. Previous research $[50,63]$ has shown that perceived behavioural control can be positively linked to the purchase intention. As the theory and previous research suggest, we propose that:

Hypothesis 1 (H1). Attitude towards remanufactured products is positively related to sustainable purchasing.

Hypothesis 2 (H2). Subjective norm associated with remanufactured products is positively related to sustainable purchasing.

Hypothesis 3 (H3). Perceived behavioural control associated with the availability of remanufactured products positively influences sustainable purchasing.

Marketing variables derived from previous research were linked with the attitude variable because consumers evaluate favourable or unfavourable variables. The variable 
'environmental knowledge' (EK) represents the knowledge level regarding environmental performance associated with green products. In our context, environmental performance refers to recycling, pollution and waste treatment. Previous research [37,63-65] suggests that knowledge among consumers is beneficial when making decisions. The fact that TPB is less centred around the individual's cognitions [55] or environmental knowledge, is not something that is being evaluated. In this paper, environmental knowledge predicts environmental concern (E). The variable 'environmental concern' represents the consumer's perception and physical support for the process of minimizing environmental impacts. In this context, it reflects the value added by environmental labels on green products and the consumer's willingness to service and repair products by themselves, thereby supporting the process of repairing, reusing and remanufacturing products [66-68]. Thus, this variable deals with extending a product's life. Previous research $[36,51,69]$ on remanufactured products demonstrates that environmental concern has a positive impact on purchasing behaviour and the perceived value. Thus, we propose that:

Hypothesis 4a (H4a). Environmental knowledge associated with remanufactured products positively influences environmental concern.

Hypothesis $4 \mathbf{b}(\mathbf{H} 4 \mathbf{b})$. Environmental concern associated with remanufactured products positively influences the consumer's attitude.

The variable 'brand equity' (B) represents the added value, as perceived by the consumer, due to the brand name [70]. Brand equity is recognized by the brand name and symbols associated with a company. Previous research $[51,69]$ has demonstrated negative and positive influences associated with the attractiveness of green products and the purchase intention. As shown in Abbey et al.'s [69] study, depending on the type of company and product, the added value of the brand differs. Because the company selling robotic lawn mowers considered them to be premium products, we propose that:

Hypothesis 5 (H5). Brand equity associated with one brand positively influences the consumer's attitude.

The variable 'perceived risk' (R) represents an expectation of a loss, which deals with the consumer's perception of the expected consequences and the uncertainty of buying a green product [71,72]. The perceived risk is relevant because consumers also consider unfavourable variables when evaluating a product [11]. In this paper, such risks include financial, time-related, and physical risk. This is appropriate for remanufactured lawn mowers, as they are expensive electronical products which require time for maintenance and can damage property. Previous research [36,37] suggests that risks are an important determinant for sustainable purchasing behaviour. We propose that:

Hypothesis 6 (H6). Perceived risk associated with remanufactured products negatively influences the consumer's attitude.

The variable 'expected product quality' (PQ) represents an expectation of the product's overall excellence [32]. In this paper, as described by Garvin [73], such quality includes performance, reliability, features, conformance, aesthetics and durability. Remanufactured products, by definition, should almost be equivalent to new products, and preferably better [68]. However, Sharma et al. [74] revealed that the perceived quality among consumers is one barrier towards remanufacturing. Hazen et al. [75] further demonstrated that features, lifespan, performance and serviceability are the main predictors of the overall quality of a remanufactured product. Similar research $[36,51]$ on remanufactured products demonstrated a positive link between product quality and the intention of engaging in sustainable purchasing behaviour. Thus, we propose that: 
Hypothesis 7 (H7). Expected product quality associated remanufactured products positively influences the consumer's attitude.

The variable 'price advantages' $(\mathrm{P})$ represents how well consumers agree with the selling price [36]. Prices below the market equilibrium price tend to be more easily sold to consumers. When consumers believe that a remanufactured product is of lower quality because the previous owner did not want the product, the consumer might expect some price advantages [7]. Several studies [36,51,69] confirm that a lower price for remanufactured products results in more sales. Thus, we propose that:

Hypothesis $\mathbf{8}$ (H8). Price advantages associated with remanufactured products positively influence the consumer's attitude.

The variable 'expected service quality' (SQ) represents the consumer's expectation of a process that supports them in some way after purchasing a green product. A service agreement (warranty) can be used to promote the reliability and quality of the product after purchasing [76]. Service agreements provide a feeling of assurance that the green product will not be defective or incapable. Hazen et al. [75] revealed that service is a crucial variable when purchasing remanufactured products. Thus, we propose that:

Hypothesis 9 (H9). Expected service quality associated with remanufactured products positively influences the consumer's attitude.

\section{Methodology}

The method consists of an online survey and an analysis using a partial least squares structural equation model (PLS-SEM), which serves as an umbrella term for different statistical tools. The target population for this research was Swedish consumers who owned or were interested in robotic lawn mowers, and who were aware of remanufactured products. Sweden was chosen as a sample country because Swedish consumers are conscious of the benefits of remanufactured products [6], and because more remanufacturing firms have appeared in Sweden [77], meaning that Swedish consumers are to some extent aware and suitable for sampling. More importantly, Sweden was selected because Husqvarna was investigating the possibility of launching remanufactured robotic lawn mowers in Sweden. As demonstrated in previous research [64,75], a short description of a remanufactured products was provided in advance to make consumers aware of them. Milios and Matsumoto [6] revealed that Swedish consumers have limited product knowledge about remanufactured automotive parts. To assess each variable in the model, items were adapted from previous research (for items and adaptation, see Kabel et al. [60]). The variable, expected service quality, is a single-item construct, and that is because Husqvarna is willing to shape a customer relation with the customer after purchasing the product. Bergkvist and Rossiter [78] demonstrate that a single-item constructs are equally as valid in terms of predictive power as multiple-item constructs. Because remanufactured robotic lawn mowers are not available in the market, items were adapted in such a way that we asked for the consumer's expectations. This also made the study more exploratory in nature, as consumers might be less aware of the existence of these products. Robotic lawn mowers have been sold under the name "refurbished robotic lawn mowers" (e.g. Amazon). In research and industry, the terms remanufactured and refurbished are used differently. According to Lund [79], remanufacturing is the process of restoring worn-out products to a like-new condition. Comparing with an original new product, the remanufactured product has the same level of performance and lifetime, or sometimes even better. Refurbishment is when a product is repaired and cleaned to a like-new condition [80]. For the electronical market, the term refurbishment is more commonly used and is easier understood by the market [81]. Within this paper we are using the terms synonymously as the processes for remanufactured and refurbished robot lawn movers are the same. 
As in previous research $[6,61,64]$ on sustainable consumption, a seven-point Likerttype scale was used. The scale ranged from "completely disagree" (1) to "completely agree" (7). To assess the relevance, that is the content validity, a pre-test was conducted. First, three academics from the disciplines of quality management and manufacturing engineering at Linköping University (Sweden) were asked to review the survey. The survey was then changed accordingly, after which it was sent to five industry experts from Husqvarna. The survey was then sent electronically to 134 participants who had recently purchased robotic lawn mowers. Only time for purchase determined this selection of participants. The survey was also published in a closed Facebook group targeting Husqvarna robotic lawn mowers users. Husqvarna recommended using this Facebook group, as most of its retailers held personal information about their customers. This sampling technique is a limitation of this research because it is based on a non-random basis. The survey consisted of an introduction to the survey, demographic items and items related to the above-mentioned variables. The sample demographics are shown in Table 2 . The age group, form of education and monthly income of the participants were fairly distributed. Most of the participants were males $(89 \%)$. The high proportion of males is a limitation influencing the generalization of the result. The survey was carried out April 2019. After the first survey was sent out, three reminders were sent. Ultimately, 118 acceptable responses came back and were used in the analysis. Of these 118 responses, 15 responses came from participants that recently purchased robotic lawn mowers and 103 came from the closed Facebook group.

Table 2. Demographic information from survey.

\begin{tabular}{|c|c|c|}
\hline Demographic & Option & Percent (Frequency) \\
\hline \multirow[t]{3}{*}{ Gender } & Male & 89 (105) \\
\hline & Female & $9(11)$ \\
\hline & $\mathrm{N} / \mathrm{A}$ & $2(2)$ \\
\hline \multirow[t]{7}{*}{ Age } & $18-25$ & $3(4)$ \\
\hline & $26-35$ & $10(12)$ \\
\hline & $36-45$ & $33(39)$ \\
\hline & $46-55$ & $27(32)$ \\
\hline & $56-65$ & $14(16)$ \\
\hline & $65+$ & $12(14)$ \\
\hline & $\mathrm{N} / \mathrm{A}$ & $1(1)$ \\
\hline \multirow[t]{6}{*}{ Education } & $\begin{array}{c}\text { Elementary school, secondary school } \\
\text { or similar }\end{array}$ & $2(2)$ \\
\hline & $\begin{array}{l}\text { Two-year upper secondary school or } \\
\text { vocational school }\end{array}$ & $14(16)$ \\
\hline & Three- or four-year secondary school & $34(40)$ \\
\hline & $\begin{array}{c}\text { University or college, less than } \\
\text { three years }\end{array}$ & $18(21)$ \\
\hline & $\begin{array}{l}\text { University or college, three years } \\
\text { or longer }\end{array}$ & $29(34)$ \\
\hline & $\mathrm{N} / \mathrm{A}$ & $4(5)$ \\
\hline \multirow[t]{7}{*}{ Household's monthly income } & 0-1999 euro & $1(1)$ \\
\hline & 2000-3999 euro & $4(5)$ \\
\hline & 4000-5999 euro & $28(33)$ \\
\hline & 6000-7999 euro & $32(38)$ \\
\hline & 8000-9999 euro & $14(17)$ \\
\hline & 10,000 euro or more & $12(14)$ \\
\hline & $\mathrm{N} / \mathrm{A}$ & $8(10)$ \\
\hline
\end{tabular}

Note: N/A = not answered.

This sample size exceeds the recommended minimum for PLS-SEM, that is 100 samples [82,83]. As in Milios and Matsumoto's [6] study, we also asked consumers whether they had purchased any remanufactured product previously. A total of 13 percent $(n=15)$ mentioned that they had experience of purchasing remanufactured products. 


\section{Predicting Sustainable Purchase Intention}

PLS-SEM using SmartPLS3 was preferred over covariance-based structural equation modelling (CB-SEM) because: (1) it relates to consumer behaviour, (2) the research objective is to predict, (3) the model is an extension of an existing theory, (4) the model is complex and has many variables, (5) the sample size is low, and (6) because the data is not normal [82,84-86]. To test the research model, a two stage-approach was used as suggested by Anderson and Gerbing [87]. In the first stage, the measures in the model were checked with controls of consistency reliability, convergent validity, and discriminant validity. In the second stage, the weights and the significance of the hypothesized relations were assessed.

\subsection{Measurement Model Assessment}

In this paper, a reflective measurement model was used. This is when the construct (variable) causes the measure (or indicator variable) [88]. In reflective measurement models, the measures predicting one construct should be highly correlated [82]. When assessing a reflective measurement model, Hair et al. [84] recommend reviewing the composite reliability, Cronbach's alpha, factor loadings, average variance extracted, Fornell-Larcker criterion and cross-loadings. Composite reliability for all the variables in our measurement model exceeded the threshold value of 0.7. Also, Cronbach's alphas for all variables were acceptable, but for some at the lower limit of between 0.6 and 0.7 [89]. According to Cronbach [90], this criterion of 0.7 can be too strict. The average variances extracted were all above 0.5 [84]. All the loadings of the measures in the model exceeded the recommended value of 0.5 [91]. Despite this, some researchers [11] suggest an even greater value of above 0.6 or 0.7 . As this research is exploratory in nature, factor loadings between 0.6 to 0.7 are adequate [84]. As seen in Table 3, all the controls exceeded the common acceptance levels. To show evidence of discriminant validity, the average variance extracted for each variable should be higher than the variable's highest squared correlation with any other variable $[84,92]$. As seen in Table 4 , the average variance extracted exceeded the squared correlation coefficient for any other variable. For a single-item construct, the square root of average variance is equal to one. Additionally, all the loadings for each item exceeded the cross-loadings, which also confirms discriminant validity. To assess common method bias in PLS-SEM, the variance inflation factor (VIF) should take values under 3.3 [93]. This analysis was performed to detect any collinearity problems between the predictive constructs. After a full collinearity test, the inner VIF values for the constructs, were between 1.0 and 2.0, this indicating the absence of collinearity. This also illustrates that the model is considered free of common method bias. In summary, all the controls for convergent validity, discriminant validity and consistency reliability exceeded the acceptance levels, meaning that the measurement model is appropriate for assessing the structural model and its hypotheses.

Table 3. Consistency reliability and convergent validity (Modified from Kabel et al. [60]).

\begin{tabular}{|c|c|c|c|c|c|c|c|}
\hline Construct & Item & Mean * & SD & Factor loading & CA & CR & AVE \\
\hline \multirow[t]{3}{*}{ Attitude } & A1 & 5.22 & 1.73 & 0.937 & 0.914 & 0.946 & 0.85 \\
\hline & $\mathrm{A} 2$ & 5.47 & 1.65 & 0.879 & & & \\
\hline & A3 & 5.41 & 1.70 & 0.953 & & & \\
\hline \multirow[t]{3}{*}{ Perceived behavioural control } & $\mathrm{C} 1$ & 1.75 & 1.52 & 0.932 & 0.909 & 0.943 & 0.68 \\
\hline & $\mathrm{C} 2$ & 1.63 & 1.41 & 0.943 & & & \\
\hline & $\mathrm{C} 3$ & 1.50 & 1.42 & 0.884 & & & \\
\hline \multirow[t]{3}{*}{ Purchase intention } & I1 & 5.24 & 1.85 & 0.929 & 0.894 & 0.935 & 0.83 \\
\hline & $\mathrm{I} 2$ & 5.13 & 1.87 & 0.943 & & & \\
\hline & I3 & 4.06 & 1.95 & 0.853 & & & \\
\hline Subjective norm & SN1 & 4.41 & 1.58 & 0.730 & 0.610 & 0.789 & 0.56 \\
\hline
\end{tabular}


Table 3. Cont.

\begin{tabular}{|c|c|c|c|c|c|c|c|}
\hline Construct & Item & Mean * & SD & Factor loading & CA & CR & AVE \\
\hline & SN2 & 5.54 & 1.51 & 0.685 & & & \\
\hline & SN3 & 4.78 & 1.73 & 0.815 & & & \\
\hline \multirow[t]{3}{*}{ Environmental concern } & E1 & 5.46 & 1.70 & 0.779 & 0.635 & 0.798 & 0.57 \\
\hline & E2 & 6.10 & 1.25 & 0.663 & & & \\
\hline & E3 & 6.03 & 1.50 & 0.813 & & & \\
\hline \multirow[t]{3}{*}{ Environmental knowledge } & EK1 & 5.78 & 1.40 & 0.911 & 0.900 & 0.938 & 0.83 \\
\hline & EK2 & 5.97 & 1.24 & 0.939 & & & \\
\hline & EK3 & 5.68 & 1.49 & 0.889 & & & \\
\hline \multirow{6}{*}{ Expected product quality } & PQ1 & 4.32 & 1.84 & 0.743 & 0.906 & 0.928 & 0.68 \\
\hline & PQ2 & 4.77 & 1.96 & 0.840 & & & \\
\hline & PQ3 & 4.60 & 2.06 & 0.861 & & & \\
\hline & PQ4 & 4.86 & 1.87 & 0.808 & & & \\
\hline & PQ5 & 5.11 & 1.78 & 0.876 & & & \\
\hline & PQ6 & 5.98 & 1.50 & 0.822 & & & \\
\hline \multirow{3}{*}{ Perceived risk } & $\hat{\mathrm{R} 1}$ & 3.40 & 2.13 & 0.659 & 0.631 & 0.781 & 0.55 \\
\hline & $\mathrm{R} 2$ & 2.72 & 1.64 & 0.915 & & & \\
\hline & $\mathrm{R} 3$ & 4.10 & 1.66 & 0.619 & & & \\
\hline Expected service quality & SQ1 & 6.03 & 1.31 & SI & SI & SI & SI \\
\hline \multirow[t]{3}{*}{ Price advantages } & $\mathrm{P} 1$ & 6.15 & 1.39 & 0.823 & 0.620 & 0.794 & 0.56 \\
\hline & $\mathrm{P} 2$ & 4.83 & 1.78 & 0.73 & & & \\
\hline & P3 & 6.74 & 0.87 & 0.694 & & & \\
\hline \multirow[t]{2}{*}{ Brand equity } & B1 & 5.99 & 1.53 & 0.982 & 0.679 & 0.821 & 0.70 \\
\hline & B2 & 5.83 & 1.68 & 0.666 & & & \\
\hline
\end{tabular}

Note: $\mathrm{SI}=$ single item, $\mathrm{SD}=$ standard deviation, ${ }^{*}=$ seven-point scale. $\mathrm{CA}=$ Cronbach's alpha, $\mathrm{CR}=$ composite reliability, $\mathrm{AVE}=$ average variance extracted.

Table 4. Discriminant validity (Modified from Kabel et al. [60]).

\begin{tabular}{|c|c|c|c|c|c|c|c|c|c|c|c|c|}
\hline & No. Items & A & B & E & EK & SQ & $\mathbf{R}$ & $\mathbf{P}$ & $P Q$ & $\mathrm{C}$ & I & SN \\
\hline $\mathrm{A}$ & 3 & $0.92 *$ & & & & & & & & & & \\
\hline B & 2 & 0.17 & 0.84 * & & & & & & & & & \\
\hline $\mathrm{E}$ & 3 & 0.38 & 0.04 & $0.76^{*}$ & & & & & & & & \\
\hline EK & 3 & 0.61 & 0.11 & 0.50 & 0.91 * & & & & & & & \\
\hline SQ & 1 & 0.34 & 0.10 & 0.26 & 0.40 & $1.00 *$ & & & & & & \\
\hline $\mathrm{R}$ & 3 & -0.39 & -0.01 & -0.28 & -0.28 & -0.03 & 0.74 * & & & & & \\
\hline $\mathrm{P}$ & 3 & 0.45 & 0.22 & 0.44 & 0.42 & 0.36 & -0.10 & 0.75 * & & & & \\
\hline PQ & 6 & 0.56 & 0.14 & 0.39 & 0.45 & 0.35 & -0.54 & 0.44 & 0.83 * & & & \\
\hline $\mathrm{C}$ & 3 & 0.09 & -0.16 & 0.00 & -0.03 & -0.08 & 0.03 & 0.07 & 0.09 & $0.92 *$ & & \\
\hline I & 3 & 0.86 & 0.07 & 0.34 & 0.51 & 0.31 & -0.48 & 0.44 & 0.62 & 0.18 & 0.91 * & \\
\hline $\mathrm{SN}$ & 3 & 0.68 & 0.18 & 0.42 & 0.46 & 0.23 & -0.32 & 0.37 & 0.48 & 0.01 & 0.69 & 0.75 * \\
\hline
\end{tabular}

Note: * represents the square root of average variance extracted, while the other value represents the squared correlation coefficients.

\subsection{Structural Model Assessment}

To evaluate the structural model, Hair et al. [84] suggest reviewing the coefficient of determination $\left(R^{2}\right)$, weights $(\beta)$, t-values and significance. To assess the hypothesis, a two-tailed t-test with 500 bootstrap samples was used. The bootstrap sample enables the weights to be tested for significance. Hypotheses are presented in Table 5 and the path model in Figure 2. Of ten proposed hypotheses, seven were supported with a 90\%, 95\% or 99\% confidence level.

As expected, hypotheses $\mathrm{H} 1, \mathrm{H} 2$ and $\mathrm{H} 3$, explained by TPB, depicted a significant result with a 99\% confidence level. The consumer's purchase intension was for the most part influenced by his or her attitude and evaluation of the remanufactured product $(\beta=0.715)$. This was followed by social pressure from other important individuals $(\beta=0.197)$ and the availability of remanufactured products $(\beta=0.116)$. Altogether, they accounted for $77 \%$ of the total variance in purchase intention $\left(R^{2}=0.770\right)$. Hair et al. [85] point out that 
$R^{2}$ values correspond to the explanatory power and model fit of the dependent variable using its independent variables. $R^{2}$ values between 0.75 and 0.9 are considered substantial. $R^{2}$ values above 0.9 can indicate overfit of a model [85]. Using the marketing variables from previous research, hypotheses $\mathrm{H} 4 \mathrm{a}, \mathrm{H} 6, \mathrm{H} 7$ and $\mathrm{H} 8$ were also supported. The consumer's attitude towards remanufactured products was significantly influenced by the expected product quality $(\beta=0.261)$, meaning that consumers with high expectations of product quality also had a positive evaluation of the remanufactured product. This was followed by price advantages $(\beta=0.206)$ and the perceived risk $(\beta=-0.202)$. The consumer's attitude was not significantly influenced by the expected service quality $(\beta=0.144)$, environmental concern $(\beta=0.089)$ or brand equity $(\beta=0.072)$. Altogether, the variables predicting the consumer's attitude towards remanufactured products explain $41.2 \%$ of the total variance $\left(R^{2}=0.412\right)$. Hair et al. [85] state that $R^{2}$ values between 0.25 and 0.5 are moderate. Environmental knowledge significantly predicts environmental concern $(\beta=0.495)$. Overall, $24.5 \%$ of the total variance is explained by environmental concern $\left(R^{2}=0.245\right)$.

Table 5. Weight ( $\beta$ ) and hypothesis testing (Modified from Kabel et al. [60]).

\begin{tabular}{ccccc}
\hline Hypothesis & $\boldsymbol{\beta}$ & t-Value & $\boldsymbol{p}$-Value & Supported? \\
\hline H1: Attitude $\rightarrow$ Purchase intention & 0.715 & 12.024 & $0.000^{* * *}$ & Yes \\
H2: Subjective norm $\rightarrow$ Purchase intention & 0.197 & 3.160 & $0.001^{* * *}$ & Yes \\
H3: Perceived behavioural control $\rightarrow$ & 0.116 & 3.863 & $0.000^{* * *}$ & Yes \\
$\quad$ Purchase intention & & & & \\
H4a: Environmental knowledge $\rightarrow$ & 0.495 & 4.969 & $0.000^{* * *}$ & Yes \\
$\quad$ Environmental concern & 0.089 & 0.945 & 0.368 & No \\
H4b: Environmental concern $\rightarrow$ Attitude & 0.072 & 0.811 & 0.391 & No \\
H5: Brand equity $\rightarrow$ Attitude & -0.202 & 2.045 & $0.041^{* *}$ & Yes \\
H6: Perceived risk $\rightarrow$ Attitude & 0.261 & 2.186 & $0.029^{* *}$ & Yes \\
H7: Expected product quality $\rightarrow$ Attitude & 0.206 & 1.811 & $0.071^{*}$ & Yes \\
H8: Price advantages $\rightarrow$ Attitude & 0.144 & 1.613 & 0.144 & No \\
H9: Expected service quality $\rightarrow$ Attitude & 0.4 &
\end{tabular}
Note: ${ }^{* * *}=p<0.01,{ }^{* *}=p<0.05$ and $^{*}=p<0.1$.

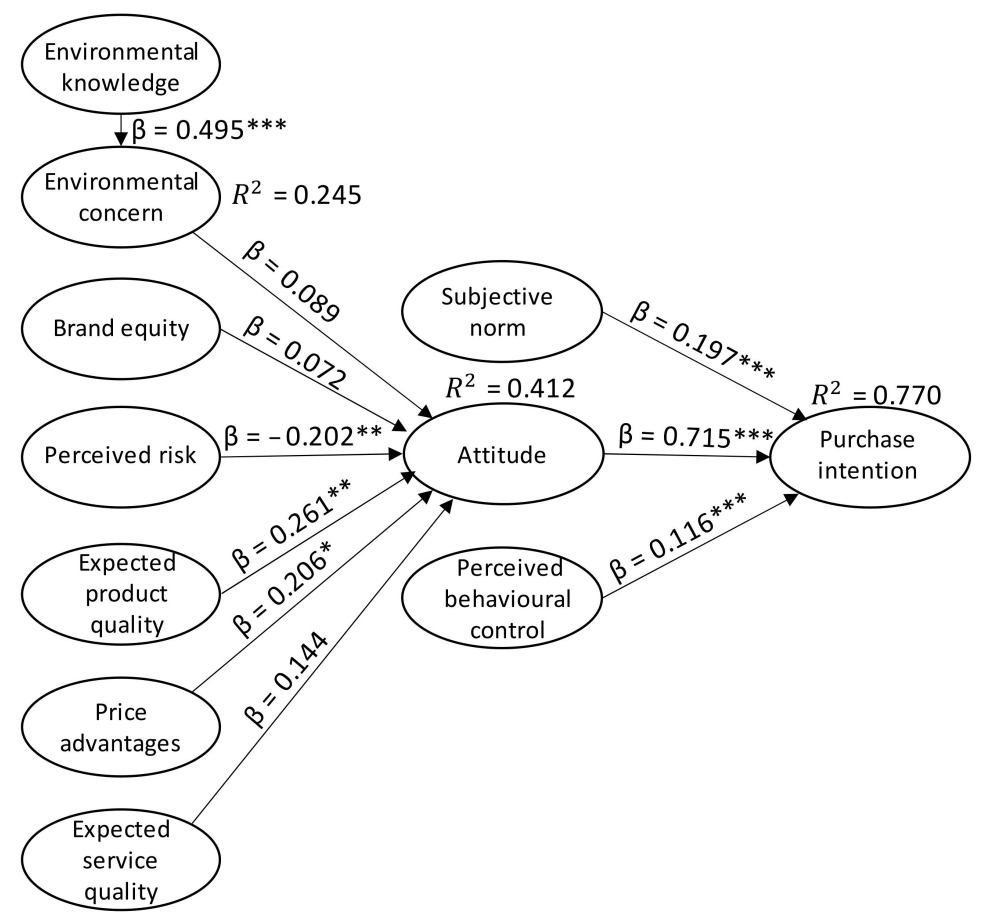

Figure 2. Structural model results (Note: ${ }^{* *}=p<0.01{ }^{* *}=p<0.05$ and ${ }^{*}=p<0.1$ ) (Modified from Kabel et al. [60]). 


\section{Discussion and Implications}

This research suggests, when using TPB, that the consumer's own evaluation influences his or her purchase intention the most, and external environment-which here corresponds to the availability of remanufactured products and pressure from other individualsthe least. Expectations related to product quality, price and risk significantly influenced attitude and the consumer's evaluation the most. Likewise, Haws and Naylor [94] reports that consumers engage in sustainable consumption because of their personal and environmental resources. That is, their own capability to use their physical and financial resources in a wise way. Regarding the objective product quality, when examining the mean (from Table 2), product performance (PQ6) was the most important indicator followed by conformance (PQ5) and aesthetics (PQ4). When it comes to perceived risk, consumers tended, based on their expectations, to spend more time compared to a new product (R3), followed by safety (R1) and financial risk (R2). To further validate our findings, results were compared with similar research. As in Milios and Matsumoto's [6] study, Swedish consumers possess knowledge about the benefits associated with a remanufactured robotic lawn mower (EK1-EK3). Other studies [37,95] have also found positive links between knowledge and the variables, perceived value, perceived consumer effectiveness and green trust. Wei et al. [96] demonstrated that environmental involvement leads to higher cognitive elaboration and a positive attitude towards green products. More surprisingly, the variable 'environmental concern', as in Michaud and Llerena's [65] study, did not provide any evidence that consumers were more willing to pay for a remanufactured product. This paper supports Hazen et al.'s [75] evidence that the quality factors for remanufactured products are performance, durability, serviceability and features. In this paper, we found that time risk associated with servicing and maintenance is one barrier, and this is closely related to durability and serviceability. The key contradictions from previous literature are related to the underlying theory with its assumptions, and the pathway of constructs. In contrast to Jimenez-Parra et al. [51], we identified that for remanufactured robotic lawn mowers, the brand name and reputation did not have a significant impact on the consumers' attitude.

This paper also provides much needed implications for research and practice [97]. The primary contribution is a theoretical basis and a contribution to the foundation of how consumers evaluate remanufactured products. As with other prediction-based models, TPB is a general model, providing a holistic view of how certain variables influence the purchase intention. From this generic result, remanufacturing firms can draw up appropriate circular marketing and remanufacturing strategies. First and most importantly, to ensure a positive evaluation of the remanufactured robotic lawn mowers, advertisements and dialogues need to be centred around the product's performance, durability (time risk) and price. Second, as informed by the positive influence of subjective norm, promoting firm-to-consumer and consumer-to-consumer interactions (e.g., advertisements, information about the benefits, feedback forms or activity on social media) would also benefit remanufacturing firms. The availability of remanufactured products is low; therefore, an increase in marketing activity would automatically benefit the consumer's ability to perform this purchasing behaviour. These marketing activities should promote marketplaces for remanufactured products, making it clear where consumers can turn to.

\section{Conclusions and Future Research}

This research examined the consumer's expectations and willingness to engage in sustainable purchasing behaviour when considering buying remanufactured robotic lawn mowers. This research demonstrates, using a survey-based methodology, that the consumer's attitude is the main determinant when buying a remanufactured robotic lawn mower. Consumers assess different variables to support their own personal interest and to maximize benefit and lessen the external environment (availability and social pressure). To obtain a positive evaluation of the remanufactured robotic lawn mower, consumers value product quality and price reductions. Also, consumers who do not anticipate a 
risk with remanufactured robotic lawn mowers had a positive evaluation and were more willing to engage in sustainable purchasing behaviour. In more concrete terms, consumers value performance and price reductions, and worry about how long the remanufactured robotic lawn mower will remain functional. This research also reveals that the consumer's environmental knowledge is sufficient and that this has a positive influence on the environmental concern. However, the environmental concern does not significantly influence the consumer's attitude towards remanufactured robotic lawn mowers. To this end, this research has some limitations in terms of its generalizability. This research involved Swedish participants who were asked about a remanufactured robotic lawn mower. Because a small proportion of the Swedish population has a robotic lawnmower, and Husqvarna accounting for a dominant share of sales in Sweden, it is easier for customers to relate to Husqvarna. The respondents were informed that the study was designed and performed by researchers at Linköping University. Despite these limitations, this research revealed new insight that is consistent with previous research. Future research should focus on a dispersed sample using a random sampling technique with different types of remanufactured products. Other (or a combination of other) prediction-oriented theories can be used to explore the consumer's willingness to engage in sustainable purchasing behaviour of remanufactured products. We also stress the importance of more theoretical syntheses of theories to gain more insight into why consumers engage in sustainable behaviour. This is important when capturing the full picture. Marketing and remanufacturing need to focus on influencing variables, such as performance, durability (time risk) and price. This research can be used to increase generalizability, that is to create a common understanding about the consumer's perception of remanufactured products. This paper provides direction and guidance for the formation of circular models, practices and principles.

Author Contributions: D.K.: Conceptualization, Methodology, Validation, Formal analysis, Investigation, Writing —original draft, Visualization. M.E.: Methodology, Writing—review \& editing, Visualization. E.S.: Conceptualization, Writing-review \& editing, Supervision, Project administration, Funding acquisition. All authors have read and agreed to the published version of the manuscript.

Funding: This research was funded by VINNOVA, Sweden's innovation agency, and its “Challengedriven innovation initiative" research programme and "ElevatoRe: Elevate remanufacturing to EEE manufacturers' strategy towards a circular economy" research project (Dnr: 2018-00330).

Institutional Review Board Statement: Not applicable.

Informed Consent Statement: Not applicable.

Data Availability Statement: Not applicable.

Acknowledgments: The authors would like to thank Bonnie Poksinska and Simon Ahlstedt at Linköping University for their support in the execution of this project and Jonas Willaredt, Sustainability Manager at Husqvarna, for his involvement in our research.

Conflicts of Interest: The authors declare no conflict of interest. The funders had no role in the design of the study; in the collection, analyses, or interpretation of data; in the writing of the manuscript, or in the decision to publish the results.

\section{References}

1. Lewandowski, M. Designing the business models for circular economy-Towards the conceptual framework. Sustainability 2016, 8, 43. [CrossRef]

2. Kircherr, J.; Reike, D.; Hekkert, M. Conceptualizing the circular economy: An analysis of 114 definitions. Resour. Conserv. Recycl. 2017, 127, 221-232. [CrossRef]

3. Sundin, E.; Bras, B. Making functional sales environmentally and economically beneficial through product remanufacturing. J. Clean. Prod. 2005, 13, 913-925. [CrossRef]

4. Govindan, K.; Hasanagic, M. A systematic review on drivers, barriers, and practices towards circular economy: A supply chain perspective. Int. J. Prod. 2018, 56, 278-311. [CrossRef]

5. Jansson, K.; Vatanen, S.; Karvonen, L.; Behm, K.; Waugh, R.; Fitzsimons, D.; Sundin, E.; Parker, D. D6.3 Targeted Recommendation for Horizon 2020. European Remanufacturing Network Grant Agreement No. 645984. 2017. Available online: https: / www. remanufacturing.eu/pdf/story/11a98ee6c096c15ce182.pdf (accessed on 10 February 2021). 
6. Milios, L.; Matsumoto, M. Consumer Perception of Remanufactured Automotive Parts and Policy Implications for Transitioning to a Circular Economy in Sweden. Sustainability 2019, 11, 6264. [CrossRef]

7. Govindan, K.; Shankar, K.M.; Kannan, D. Application of fuzzy analytic network process for barrier evaluation in automotive parts remanufacturing towards cleaner production-A study in an Indian scenario. J. Clean. Prod. 2016, 114, 199-213. [CrossRef]

8. Karvonen, I.; Jansson, K.; Behm, K.; Vatanen, S.; Parker, D. Identifying recommendations to promote remanufacturing in Europa. J. Remanuf. 2017, 7, 159-179. [CrossRef]

9. Vogt Duberg, J.; Johansson, G.; Sundin, E.; Kurilova-Palisaitiene, J. Prerequisite factors for original equipment manufacturer remanufacturing. J. Clean. Prod. 2020, 270, 122-309. [CrossRef]

10. O'Rourke, D.; Lollo, N. Transforming consumption: From decoupling, to behavior change, to system changes for sustainable consumption. Annu. Rev. Environ. Resour. 2015, 40, 233-259. [CrossRef]

11. Ajzen, I. The theory of planned behavior. Organ. Behav. Hum. Decis. Process. 1991, 50, 179-211. [CrossRef]

12. White, K.; MacDonnell, R.; Dahl, D.W. It's the mind-set that matters: The role of construal level and message framing in influencing consumer efficacy and conservation behaviors. J. Mark. Res. 2011, 48, 472-485. [CrossRef]

13. White, K.; Simpson, B. When do (and don't) normative appeals influence sustainable consumer behaviors? J. Mark. 2013, 77, 78-95. [CrossRef]

14. Sternberg, R.J. A triangular theory of love. Psychol. Rev. 1986, 93, 119-135. [CrossRef]

15. Gross, J.J. The emerging field of emotion regulation: An integrative review. Rev. Gen. Psychol. 1998, 2, 271-279. [CrossRef]

16. Frijda, N.H. The Emotion; Cambridge University Press: Cambridge, UK, 1986.

17. Dong, X.; Liu, S.; Li, H.; Yang, Z.; Liang, S.; Deng, N. Love of nature as a mediator between connectedness to nature and sustainable consumption behavior. J. Clean. Prod. 2020, 242, 1-11. [CrossRef]

18. Kadic-Maglajlic, S.; Arslanagic-Kalajdzic, M.; Micevski, M.; Dlacic, J.; Zabkar, V. Being engaged is a good thing: Understanding sustainable consumption behavior among young adults. J. Bus. Res. 2019, 104, 644-654. [CrossRef]

19. Wang, J.; Wu, L. The impact of emotions on the intention of sustainable consumption choices: Evidence from a big city in an emerging country. J. Clean. Prod. 2016, 126, 325-336. [CrossRef]

20. Stern, P.C.; Dietz, T.; Abel, G.; Guagnano, G.; Kalof, L. A value-belief-norm theory of support for social movement: The case of environmentalism. Hum. Ecol. Rev. 1999, 6, 81-97.

21. Schwartz, S.H. An overview of the Schwartz theory of basic values. Online Read. Psychol. Cult. 2012, 2, 1-20. [CrossRef]

22. Sheth, J.N.; Newman, B.I.; Gross, B.L. Why we buy what we buy: A theory of consumption values. J. Bus. Res. 1991, 22, 159-170. [CrossRef]

23. Kang, J.; Moreno, F. Driving values to actions: Predictive modeling for environmentally sustainable product purchases. Sustain. Prod. 2020, 23, 224-235. [CrossRef]

24. Jacobs, K.; Petersen, L.; Hörisch, J.; Battenfeld, D. Green thinking but thoughtless buying? An empirical extension of the value-attitude-behaviour hierarchy in sustainable clothing. J. Clean. Prod. 2018, 203, 1155-1169. [CrossRef]

25. Thogersen, J.; Zhou, Y.; Huang, G. How stable is the value basis for organic food consumption in China? J. Clean. Prod. 2016, 134, 214-224. [CrossRef]

26. Biswas, A.; Roy, M. Leveraging factors for sustained green consumption behavior based on consumption value perceptions: Testing the structural model. J. Clean. Prod. 2015, 95, 332-340. [CrossRef]

27. Liobikiene, G.; Liobikas, J.; Brizga, J.; Juknys, J. Materialistic values impact on pro-environmental behaviour: The case of transition country as Lithunia. J. Clean. Prod. 2020, 244, 1-10. [CrossRef]

28. Lindenberg, S.; Steg, L. Normative, gain and hedonic goal-frames guiding environmental behavior. J. Soc. Issues 2007, 65, 117-137. [CrossRef]

29. Rogers, E.M. Diffusion of Innovations, 5th ed.; Free Press: New York, NY, USA, 2003.

30. Ram, S. A Model of Innovation Resistance, Advances in Consumer Research, 14th ed.; Wallendorf, M., Anderson, P., Eds.; Association for Consumer Research: Provo, UT, USA, 1987; pp. 208-212.

31. Kahneman, D. Prospect theory: An analysis of decision under risk. Econometrica 1979, 47, 263-291. [CrossRef]

32. Zeithaml, V.A. Consumer perceptions of price, quality, and value: A means-end model and synthesis of evidence. J. Mark. 1988, 52, 2-22. [CrossRef]

33. Brockner, J.; Higgins, E.T. Regulatory focus theory: Implications for the study of emotions at work. Organ. Behav. Hum. Decis. Process. 2001, 86, 35-66. [CrossRef]

34. Starmer, C. Developments in Non-expected Utility Theory: The Hunt for a Descriptive Theory of Choice under Risk. J. Econ. Lit. 2000, 38, 332-382. [CrossRef]

35. Liobikiene, G.; Grinceviciene, S.; Bernatoniene, J. Environmentally friendly behaviour and green purchase in Austria and Lithuania. J. Clean. Prod. 2017, 142, 3789-3797. [CrossRef]

36. Wang, Y.; Hazen, B.T.; Mollenkopf, D.A. Consumer value considerations and adoption of remanufactured products in closed-loop supply chains. Ind. Manag. 2018, 118, 480-498. [CrossRef]

37. Wang, Y.; Hazen, B.T. Consumer product knowledge and intention to purchase remanufactured products. Int. J. Prod. Econ. 2016, 181, 460-469. [CrossRef]

38. Hazen, B.J.; Overstreet, R.E.; Jones-Farmer, A.; Field, H.S. The role of ambiguity tolerance in consumer perception of remanufactured products. Int. J. Prod. Econ. 2012, 135, 781-790. [CrossRef] 
39. Wang, Y.; Huscroft, J.; Hazen, B.T.; Zhang, M. Green information, green certification and consumer perceptions of remanufactured automobile parts. Resour. Conserv. Recycl. 2018, 128, 187-196. [CrossRef]

40. Cleveland, M.; Robertson, J.L.; Volk, V. Helping or hindering: Environmental locus of control, subjective enablers and constraints, and pro-environmental behaviors. J. Clean. Prod. 2020, 249, 1-12. [CrossRef]

41. Kushwah, S.; Dhir, A.; Sagar, M. Understanding consumer resistance to the consumption of organic food. A study of ethical consumption, purchasing, and choice behaviour. Food Qual. Prefer. 2019, 77, 1-14. [CrossRef]

42. Bandura, A. Social Foundations of Thought and Action: A Social Cognitive Theory; Prentice-Hall: Englewood Cliffs, NJ, USA, 1986.

43. Bandura, A. Social Learning Theory; Prentice Hall: Englewood Cliffs, NJ, USA, 1977.

44. Sun, Y.; Liu, N.; Zhao, M. Factors and mechanisms affecting green consumption in China: A multilevel analysis. J. Clean. Prod. 2019, 209, 481-491. [CrossRef]

45. Yazdanpanah, M.; Feyzabad, F.R.; Forouszani, M.; Mohammadzadeh, S.; Burton, R.J.F. Predicting farmers' water conservation goals and behavior in Iran: A test of social cognitive theory. Land Use Policy 2015, 47, 401-407. [CrossRef]

46. DiMaggio, P.J.; Powell, W.W. The iron cage revisited: Institutional isomorphism and collective rationality in organizational fields. Am. Sociol. Rev. 1983, 48, 147-160. [CrossRef]

47. Jost, J.T.; Banaji, M.R. The role of stereotyping in system-justification and the production of false consciousness. Br. J. Soc. Psychol. 1994, 33, 1-27. [CrossRef]

48. Fishbein, M.; Ajzen, I. Belief, Attitude, Intention, and Behavior: An Introduction to Theory and Research; Addison-Wesley: Reading, MA, USA, 1975.

49. Fishbein, M.; Ajzen, I. Predicting and Changing Behavior: The Reasoned Action Approach, 1st ed.; Taylor \& Francis Inc.: Philadelphia, PA, USA, 2015.

50. Paul, J.; Modi, A.; Patel, J. Predicting green product consumption using theory of planned and reason action. J. Retail. Consum. Serv. 2016, 29, 123-134. [CrossRef]

51. Jimenez-Parra, B.; Rubio, S.; Vicente-Molina, M. Key drivers in the behavior of potential consumers of remanufactured products: A study on laptops in Spain. J. Clean. Prod. 2014, 85, 488-496. [CrossRef]

52. Jain, S.; Singhal, S.; Jain, N.K.; Bhaskar, K. Construction and demolition waste recycling: Investigating the role of theory of planned behavior, institutional pressures and environmental consciousness. J. Clean. Prod. 2020, 263, 1-11. [CrossRef]

53. Vainio, A.; Paloniemi, R. The complex role of attitudes toward science in pro-environmental consumption in the Nordic countries. Ecol. Econ. 2014, 108, 18-27. [CrossRef]

54. Judge, M.; Warren-Myers, G.; Paladino, A. Using the theory of planned behaviour to predict intentions to purchase sustainable housing. J. Clean. Prod. 2019, 215, 259-267. [CrossRef]

55. Ajzen, I. The theory of planned behavior: Reactions and reflections. Psychol. Health. 2011, 26, 1113-1127. [CrossRef] [PubMed]

56. Si, H.; Shi, J.; Tang, D.; Wen, S.; Miao, W.; Duan, K. Application of the theory of planned behavior in environmental science: A comprehensive bibliometric analysis. Int. J. Environ. Res. Public Health 2019, 16, 2788. [CrossRef]

57. Ajzen, I. The theory of planned behavior: Frequently asked questions. Hum. Behav. Emerg. Technol. 2020, 2, 314-324. [CrossRef]

58. Ajzen, I. Nature of operation of attitudes. Annu. Rev. Psychol. 2001, 52, 27-58. [CrossRef] [PubMed]

59. Ajzen, I.; Fishbein, M. Attitudes and the attitude-behavior relation: Reasoned and automatic processes. Eur. Rev. Soc. Psychol. 2000, 11, 1-33. [CrossRef]

60. Kabel, D.; Ahlstedt, S.; Elg, M.; Sundin, E. Consumer purchase intention of remanufactured EEE products-A study on robotic lawn mowers in Sweden. Procedia CIRP 2020, 90, 79-84. [CrossRef]

61. Zhang, B.; Yang, Y.; Bi, J. Enterprises' willingness to adopt/develop cleaner production technologies: An empirical study in Changshu, China. J. Clean. Prod. 2013, 40, 62-70. [CrossRef]

62. Barbarossa, C.; Beckmann, S.C.; De Pelsmacker, P.; Moons, I.; Gwozdz, W. A self-identity based model of electric car adoption intention: A cross-cultural comparative study. J. Environ. Psychol. 2015, 42, 149-160. [CrossRef]

63. Kumar, B. Theory of Planned Behaviour Approach to Understand the Purchasing Behaviour for Environmentally Sustainable Products. 2012. Available online: http:/ / www.iimahd.ernet.in/assets/snippets/workingpaperpdf/10260621182012-12-08.pdf (accessed on 12 August 2020).

64. Wang, Y.; Wiegerinck, V.; Krikke, H.; Zhang, H. Understanding the purchase intention towards remanufactured product in closed-loop supply chains: An empirical study in China. Int. J. Phys. Distrib. Logist. Manag. 2013, 43, 866-888. [CrossRef]

65. Michaud, C.; Llerena, D. Green consumer behaviour: An experimental analysis of willingness to pay for remanufactured products. Bus. Strategy Environ. 2011, 20, 408-420. [CrossRef]

66. D'Souza, C.; Taghian, M.; Lamb, P. An empirical study on the influence of environmental labels on consumers. Corp. Commun. 2006, 11, 162-173. [CrossRef]

67. King, A.M.; Burgess, S.C.; Ijomah, W.; McMahon, C.A. Reducing waste: Repair, recondition, remanufacture, or recycle. Sustain. Dev. 2006, 14, 257-267. [CrossRef]

68. Ijomah, W.L.; Bennett, J.P.; Pearce, J. Remanufacturing: Evidence of environmentally conscious business practice in the UK. In Proceedings of the First International Symposium on Environmentally Conscious and Inverse Manufacturing, Tokyo, Japan, 1-3 February 1999; IEEE: Piscataway, NJ, USA, 1999; pp. 192-196.

69. Abbey, J.D.; Meloy, M.G.; Guide, V.D.R.; Atalay, S. Remanufacturing products in closed-loop supply chains for consumer goods. Prod. Oper. Manag. 2015, 24, 488-503. [CrossRef] 
70. Aaker, D.A. Managing Brand Equity: Capitalizing on the Value of a Brand Name; Simon \& Schuster Adult Publishing Group: New York, NY, USA, 1991.

71. Sweeney, J.C.; Souter, G.N.; Johnson, L.W. The role of perceived risk in the quality value relationship: A study in a retail environment. J. Retail. 1999, 75, 77-105. [CrossRef]

72. Dowling, G.R.; Staelin, R. A preliminary investigation into pre- and post-purchase risk perception and reduction. Eur. J. Mark. 1994, 28, 56-71.

73. Garvin, D.A. Competing on the eight dimensions of quality. Harv. Bus. Rev. 1984, 65, 101-109.

74. Sharma, V.; Garg, S.K.; Sharma, P.B. Identification of major drivers and roadblocks for remanufacturing in India. J. Clean. Prod. 2016, 112, 1882-1892. [CrossRef]

75. Hazen, B.T.; Boone, C.A.; Wang, Y. Perceived quality of remanufactured products: Construct and measure development. J. Clean. Prod. 2017, 142, 716-726. [CrossRef]

76. Alqahtani, A.Y.; Guptam, S.M. Warranty as a marketing strategy for remanufactured products. J. Clean. Prod. 2017, 161, 1294-1307. [CrossRef]

77. Sundin, E.; Tang, O.; Mårtén, E. The Swedish Remanufacturing Industry-An Overview of Present Status and Future Potential. In Proceedings of the CIRP Life Cycle Engineering Seminar-12th Edition-LCE05, Laboratoire 3S, Grenoble, France, 3-5 April 2005.

78. Bergkvist, L.; Rossiter, J.R. The predictive validity of multiple-item versus single-item measures of the same constructs. J. Mark. Res. 2007, 44, 175-184. [CrossRef]

79. Lund, R.T. Remanufacturing: The Experience of the United States and Implications for Developing Countries; CPA/83-17; The World Bank: Washington, DC, USA, 1983.

80. Rogers, D.S.; Tibben-Lembke, R.S. Going Backwards: Reverse Logistics Trends and Practices; Reverse Logistics Executive Council: Pittsburgh, PA, USA, 1999.

81. ANSI. American National Standard, RIC001.1-2016, Specifications for the Process of Remanufacturing, an American National Standard for Remanufacturing; ANSI Accredited Standards Developer: New York, NY, USA, 2016.

82. Hair, J.; Hollingsworth, C.L.; Randolph, A.B.; Chong, A.Y.L. An updated and expanded assessment of PLS-SEM in information systems research. Ind. Manag. 2017, 117, 442-458. [CrossRef]

83. Reinartz, W.J.; Haenlein, M.; Henseler, J. An empirical comparison of the efficacy of covariance-based and variance-based SEM. Int. J. Mark. Res. 2009, 26, 332-344. [CrossRef]

84. Hair, J.F.; Ringle, C.M.; Sarstedt, M. PLS-SEM: Indeed a Silver Bullet. J. Mark. Theory Pract. 2011, 19, 139-152. [CrossRef]

85. Hair, J.F.; Risher, J.J.; Sarstedt, M.; Ringle, C.M. When to use and how to report the results of PLS-SEM. Eur. Bus. Rev. 2019, 31, 2-24. [CrossRef]

86. Lowry, P.B.; Gaskin, J. Partial Least Squares (PLS) Structural Equation Modeling (SEM) for Building and Testing Behavioral Causal Theory: When to Choose It and How to Use It. IEEE Trans. Prof. Commun. 2014, 57, 123-146. [CrossRef]

87. Anderson, J.C.; Gerbing, D.W. Structural equation modeling in practice: A review and recommended two-step approach. Psychol. Bull. 1998, 103, 411-423. [CrossRef]

88. Hair, J.F.; Sarstedt, M.; Hopkins, L.; Kuppelwieser, V.G. Partial least squares structural equation modeling (PLS-SEM): An emerging tool in business research. Eur. Bus. Rev. 2014, 26, 106-121. [CrossRef]

89. Taber, K.S. The Use of Cronbach's Alpha When Developing and Reporting Research Instruments in Science Education. Res. Sci. Technol. Educ. 2018, 48, 1273-1296. [CrossRef]

90. Cronbach, L.J. My current thoughts on coefficient alpha and successor procedures. Educ. Psychol. Meas. 2004, 64, 391-418. [CrossRef]

91. Hulland, J. Use of Partial Least Squares (PLS) in Strategic Management Research: A Review of Four Recent Studies. Strateg. Manag. J. 1999, 20, 195-204. [CrossRef]

92. Fornell, C.; Larcker, D.F. Evaluating Structural Equation Models with Unobservable Variables and Measurement Error. J. Mark. Res. 1981, 18, 39-50. [CrossRef]

93. Kock, N. Common method bias in PLS-SEM: A full collinearity assessment approach. Int. J. e-Collab. 2015, 11, 1-10. [CrossRef]

94. Haws, K.L.; Winterich, K.P.; Naylor, R.W. Seeing the world through GREEN-tinted glasses: Green consumption values and responses to environmentally friendly products. J. Consum. Psychol. 2014, 24, 336-354. [CrossRef]

95. Wang, H.; Ma, B.; Bai, R. How does green product knowledge effectively promote green purchase intention? Sustainability 2019, 11, 1193. [CrossRef]

96. Wei, C.F.; Chiang, C.T.; Kou, T.C.; Lee, B.C. Toward sustainable livelihoods: Investigating the drivers of purchase behavior for green products. Bus. Strategy Environ. 2017, 26, 626-639. [CrossRef]

97. Guide, V.D.R., Jr.; Li, J. The potential for cannibalization of new products sales by remanufactured products. Decis. Sci. 2010, 41, 547-572. [CrossRef] 